\title{
Changes in the Teaching of Native Literature: the Case of Latvia
}

\author{
Elita Stikute
}

\begin{abstract}
The purpose of this study was to discover what challenges and innovations were significant in the literature curriculum after 1990. The article describes changes and updates in the methodology of literature teaching. The teaching of Latvian literature underwent major changes during the transition from an authoritarian regime to a democratic society: it was necessary to revise an old, obsessively socialised, Soviet-ideologised curriculum and develop a new curriculum focused on literature as an art of words, with special emphasis on Latvian identity. Literature and Latvian language had to be taught by recognising them as a national value, expression, and stimulus of a nation's intellectual life, guardian of historical experience, and an artistic and emotionally imaginative description of a nation's destiny. In order to actualise the new curriculum, standards in literature for primary and secondary school and curriculum exemplars were adapted and various new, modern, and methodologically diverse teaching aids and resources were developed. The literature teacher received a wide range of choices; the teacher was able to design his or her own curriculum, appropriate to the age and interests of students. The educational principles defined in the curriculum of primary and secondary education (self-expression and creativity, collaboration, and practical activities) shifted the emphasis from teacher-knowledge-provider to teacher-assistant, companion, and counselor in the teaching/learning process.
\end{abstract}

Keywords: literature as an art of words, teaching/learning standards, curriculum, teaching aids, methodology

\section{Introduction}

Literature as a subject of study has great importance in voicing universal intellectual and national values, value orientation, ethical and aesthetic upbringing, development of the emotional and mental world of the personality, and emotionally evaluating activity and attitude, self-realisation, and cocreation. After regaining independence, these aspects became especially important within the literature learning process in Latvia. I review changes in the educational system and organisation of the literature teaching/learning process and activities of Latvian language and literature teachers after 1990, as well as demonstrate the transition to new educational standards and provide curriculum development examples. The purpose of this study is to discover what challenges and innovations were significant in the literature curriculum after 1990. The article also describes changes and updates in the methodology of literature teaching. 


\section{Changes in the education system and organisation of the learning process after 1990}

The Latvian educational system underwent significant transformation during the 1990s and at the beginning of the $21^{\text {st }}$ century. It affected every school, student, and teacher. One of the main innovations of the educational system was the improvement of quality of education of native language and literature teaching: it strove to seek answers to the question - what kind of education did students really need to be best prepared for the rapidly changing and complicated world of the future? Students had to learn to find reference points in the world of values (as well as lack of values), take risks, make their own decisions, prove and stand by what they believed in, defend their viewpoint, and communicate in a world of diversity. The European Union's (EU) White Paper on education and training emphasises that the purpose of education is to prepare Europeans for gradual transition into a society in which everyone continues to study and teach others all their lives and, thus, be part of the learning society. ${ }^{1}$ In his report 'Education for the $21^{\text {st }}$ century', Jacques Delors names the ability to teach 'how to learn' as essential for being able to fit into a rapidly changing world. In the next, $21^{\text {st }}$ century, problems included in the agenda will require revision of educational goals and reevaluation of human expectations regarding study results. Broad, comprehensive understanding about learning can allow every person to discover, reveal, and enrich his/her creative potential, opening the treasures hidden in every one of us. If up to now education was perceived as the process that allowed us to reach certain goals (skills, abilities, or economic potential), then currently the opinion dominates emphasising personality development, in short, learning to be. ${ }^{2}$ Within this context, it is very important to offer education that can provide the possibility to acquire, select, arrange, manage and use information; the four most important pillars of future education are learning to know, learning to do, learning to be, and learning to live together. ${ }^{3}$

While orienting towards a return to Europe and joining the EU, Latvia also had to solve issues about its future society and its education. Achievements were described in the State Primary Education Standard goals and tasks in which the dominant role in the evaluation of learning efficiency was taken by

1 Eiropas Komisija [European Commission], Mācīšana un mācīšanās - cel̦š uz izglītotu sabiedrību [Teaching and learning - towards a learning society], Riga, Akadēmisko programmu aǵentūra, 1998 , p. 45.

2 Rīgas Pedagogijas un izglīīibas vadỉbas augstskola [Riga Teacher Training and Educational Management Academy], Nākotnes izglītības meti UNESCO starptautiskās komisijas 'Izglītība divdesmit pirmajam gadsimtam' zinojuma [Future education perspectives in the UNESCO International committee report 'Education for the $21^{\text {st }}$ century'], Riga, Vārti, 1998, p. 32.

3 Ibid., p. 19. 
the ability to cooperate, use acquired knowledge in new situations, and plan and implement work ${ }^{4}$.

Rapid increase of information and general humanisation of education took place during this period. The White Paper set the precondition for everyone to learn to think more systematically and determine his/her place in society as a user, citizen, individual, and member of the community. ${ }^{5}$ Comprehensive knowledge allows people to find their path in the acquisition of information, as well as critically evaluate information obtained from various sources.

\section{New requirements for the teacher}

Education policy decision-makers, teaching staff, and all educators were increasingly concerned with questions: What should we teach in school? What education should we offer that is suitable for the modern world? In addition, there were issues surrounding economics, cultural and technological union and diversity, and the transition to an information society. While acknowledging new accents in education, it was important to carefully evaluate past achievements of pedagogical practice and theory and determine what to maintain and develop and what to get rid of.

Society was increasingly debating about the type of knowledge needed for practical life, complaining that schools still paid a lot of attention to factual knowledge and its reproduction and that learning processes did not aid in creating a systemic worldview. Connections, links, and contexts between various subjects were seldom made. Teachers taught each subject separately without mutual consultations, ignoring the common and significant. Each teacher imposed maximum requirements and anticipated the same amount of feedback from the student, thus providing and requesting masses of information not needed for life outside the school walls and excessively burdening students. As a result, contradictions arose: education legislation documents - Latvian education concept ${ }^{6}$ and State primary education standard ${ }^{7}$ - required young people to be able to solve complex problems, evaluate various circumstances,

${ }^{4}$ Latvijas Republikas Izglìtības un zinātnes ministrija, Izglìtības satura un eksaminācijas centrs [Ministry of Education and Science of the Republic of Latvia, Center for Curriculum and Examination], Valsts pamatizglitīibas standarts [State primary education standards], Lielvārde, Lielvārds, 1998, p. 7.

5 Eiropas Komisija [European Commission], Mācišsana un mācišanās - celšs uz izglìtotu sabiedrību [Teaching and learning - towards a learning society], Riga, Akadēmisko programmu aǵentūra, 1998, p. 23.

6 Latvijas Republikas Izglìtības un zinātnes ministrija [Ministry of Education and Science of the Republic of Latvia], Latvijas Izglitïbas koncepcija [Latvian Education concept], Riga, 1997, p. 32.

7 Latvijas Republikas Izglìīibas un zinātnes ministrija, Izglīîibas satura un eksaminācijas centrs [Ministry of Education and Science of the Republic of Latvia, Center for Curriculum and Examination], Valsts pamatizglìtības standarts [State primary education standard], Lielvārde, Lielvārds, 1998, p. 32. 
consider opinions, and make decisions, but the learning process did not promote these skills.

The necessity arose to develop thinking processes through educational content and methods - fostering, promoting, and creating a suitable study environment. Several modern humanist pedagogical practices were introduced through various projects such as 'Reading and writing for the development of critical thinking' ${ }^{8}$ that altered existing stereotypes, especially emphasising the cognitive process and development of action.

The role of the teacher in the learning process changed gradually from a carrier and provider of knowledge to a consultant, assistant, ally, and cooperation partner. Student activities were the key to the learning process, but the teacher helped obtain individually significant academic achievements. It was important for every teacher to understand the need for change, be able to change with the times and adopt associated requirements, and work with new methods based on cooperation with students, creating comprehensively developed and original individuality as noted in the UNESCO report Education for the $21^{\text {st }}$ century. ${ }^{9}$ In turn, the Latvian Education concept anticipated creation of favorable circumstances for development of the individual according to his/ her skills and interests. ${ }^{10}$ To promote implementation of this goal, teachers had to review priorities in the learning process and alter organisation of work and learning tools to align the educational process with those requirements.

Every innovation enters society gradually and is not immediately accepted. There were teachers who were open to changes, accepted them, and introduced them in their pedagogical activities; they were not afraid of experimenting and were not perplexed by difficulties if something did not work out as planned. Teachers critically reviewed their teaching styles, wanted to change and upgrade their skills, and were motivated to change study methods to make the learning process more enjoyable. But some teachers still worked with old methods, afraid of the new and unknown because the old work style was tested, familiar, comfortable, and safe.

\footnotetext{
${ }^{8}$ Izglīīibas attīstības centrs [Education Development Center], Kritiskās domāšanas attīstī̌̌anas pieejas izmantošana izglìtības sistēmā - ietekme un efektivitāte Latvijā. Pētījuma rezultāti un ieteikumi [Application of the critical thinking development approach in the educational system - influence and efficiency in Latvia. Study results and recommendations], Riga, Izglitīibas attīstibas centrs, 2008. Available: http://www.iac.edu.lv/assets/Publications/Kritiskadomasana-web.pdf (accessed 11 July 2017).

${ }^{9}$ Rìgas Pedagoǵijas un izglìtības vadíbas augstskola [Riga Teacher Training and Educational Management Academy], Nākotnes izglìtības meti UNESCO starptautiskās komisijas 'Izglìtība divdesmit pirmajam gadsimtam' zinojumā [Future education perspectives in the UNESCO International committee report 'Education for the 21st century'], Riga, Vārti, 1998, p. 32.

${ }^{10}$ Latvijas Republikas Izglìtibas un zinātnes ministrija [Ministry of Education and Science of the Republic of Latvia], Latvijas Izglitibas koncepcija [Latvian Education concept], Riga, 1997, p. 4.
} 


\section{Latvian literature curriculum development: classic values and innovations}

When Latvia regained independence, the ideology-laden curriculum of the Soviet period had to be reviewed. Latvian literature as a subject was a convenient tool in the hands of the Soviet ruling in order with which to teach young people "proletarian internationalism" and "socialistic patriotism principles" - endless loyalty towards communism ideals and love towards the socialistic Homeland and other Soviet-friendly countries. The task of the student was to make conclusions about advantages of Soviet life and feel pride and joy in the Soviet Homeland (as opposed to the capitalist world) and better understand the benefits of the Soviet ruling order and feel the joy of their life, eradicate past contradictions, and raise New Soviet People who were ready to work and fight for their Homeland. ${ }^{11}$

The curriculum in Soviet schools included only the works of authors expressing ideas consistent with Soviet ideology. However, in the late 1980s, the situation changed: under Gorbachev's perestroika, literature curricula began to include biographies and work of Latvian writers who were banned during the Soviet period, such as the patriotic work of Jānis Jaunsudrabiņš (1877-1962) Piemini Latviju! [Remember Latvia], a poem acclaiming the Latvian Riflemen by Aleksandrs Čaks (1901-1950) Müžîbas skartie [Touched by Eternity], Aleksandrs Grīns (1895-1941) World War I novel Dvēseḷu putenis [Blizzard of Souls], ${ }^{12}$ a Latvian perspective of country life in Edvarts Virza's (1883-1940) Straumeni, and works by other writers who went into exile to the West after World War II. ${ }^{13}$

Up to 1992, literature curricula were determined by the Soviet Latvian People's Education Ministry under the supervision of Ërika Zimule, a Latvian Language and History Department methodologist at the Scientific Research Institute of Pedagogy. Specifics of literature as a subject were indicated in the curricula. Literature was considered a form of art and obtainable knowledge about literature was: literature history, theory, criticism, and the special significance of literature in development of the individual, teaching of general humane ethical principles, development of perception and understanding of art, and formation of the culture of feelings. Curricula issued during 1990s were created combining folklore, Latvian and foreign classic literature, and works of contemporary writers. From $5^{\text {th }}$ to $8^{\text {th }}$ grade, history was accentuated (literature was studied in historical sequence); in $9^{\text {th }}$ grade, the principles of literature forms and genres - lyrical poetry, dramaturgy and lyrico-epics were taught; and from $10^{\text {th }}$ to $12^{\text {th }}$ grade - historical or chronological literature development

\footnotetext{
${ }^{11}$ E. Stikute, Latviešu literatūras didaktika [Latvian literature didactics], Riga, RaKa, 2011, p. 119.

${ }^{12}$ Latvijas PSR Tautas izglitîbas ministrija [Ministry of Public Education of the Latvia SSR], Latviešu literatūra. Eksperimentāla programma vispārizglītojošo skolu 5.-12. klasei [Latvian literature. Experimental programme for general education schools from $5^{\text {th }}$ to $12^{\text {th }}$ grade], Riga, Latvijas PSR Tautas izglitības ministrija, 1989, p. 9.

${ }^{13}$ Ibid., p. 14.
} 
principles looked at both Latvian and foreign literature. Curricula indicate that teachers were given a choice to select specific authors and recommend literature for further reading. The approximate number of lessons needed to master a particular topic was indicated but could be changed by the teacher. Curriculum included studying literature on several levels: 1 ) analyze and learn; 2) analyze and learn by choice and abilities; 3 ) discover on the informative level. Curricula include literature theory because without the knowledge of theory it was not possible to fully understand the literary work: the level of ideas and recognition in elementary school and the level of concepts in secondary school. After the outline of content for secondary schools, an orienteering level of knowledge and skills was provided, including the ability to do, know, and recognise. Finally, curriculum planned, for each grade, the number of lessons for reading contemporary literature (5-6 lessons), independent work at the library or literary excursions (around 6 hours), and about 10 hours devoted to written works from the total amount. ${ }^{14}$

During the 1990s, Latvia began the transition to new educational documents. For each subject, this meant a change from one single mandatory curriculum and a single textbook that complied with subject standards and a mandatory level of knowledge and skills to a system that allowed teachers the freedom to choose from various curricula or develop his/her own curriculum as well as freely select textbooks and other learning aids. In 1992/1993, the primary education standard ${ }^{15}$ was adopted and the secondary education standard in 1993/1994. In 1998, the State primary education standard was re-issued, but plans to complete development of the specialised standard in all subjects was projected for 2004 .

During the transition period, the introduction of new standards for Latvian language and literature were published in small brochures by the Ministry of Education. ${ }^{16}$ They indicated the aim and tasks: develop understanding of fiction as an art form and the value of literature through teaching Latvian and foreign folklore, literature classics and contemporary works; create understanding about general humane, ethical and aesthetic values, traditional lifestyle and foster these values in perception and actions; teach national cultural perception

\footnotetext{
${ }^{14}$ Latvijas Republikas Tautas izglitïbas ministrija [Ministry of Education and Science of the Republic of Latvia], Literatūras programma 5.-12. klasei [Literature curriculum from $5^{\text {th }}$ to $12^{\text {th }}$ grade], Riga, Zvaigzne, 1990; Latvijas Republikas Tautas izglitîbas ministrija [Ministry of Education and Science of the Republic of Latvia], Literatüras programma 5.-12. klasei [Literature curriculum from $5^{\text {th }}$ to $12^{\text {th }}$ grade], Rìga, Zvaigzne, 1991.

${ }^{15}$ Officially approved and publicly available document that determines the optimum level of requirements about the processes and results to be achieved, anticipating definite necessary and sufficient qualitative and quantitative results indicators. See A. Blinkena (ed.), Pedagogiijas terminu skaidrojoša $\bar{a}$ värdnīca [Interpretative dictionary of pedagogy terms], Riga, Zvaigzne ABC, 2000, p. 163.

${ }^{16}$ Latvijas Republikas izglitiibas ministrija [Ministry of Education of the Republic of Latvia], Vidējās izglìtības standarti latviešu valodā un literatūrā [Secondary education standards in the Latvian language and literature], Rīga, Latvijas Republikas izglitīibas ministrija, 1993, pp. 9-16.
} 
and Latvian identity; promote the willingness to read and ability to experience and evaluate literary works; and create perception about the forms and genres of fiction and artistic expression possibilities. Standards included authors and their works that students should master during primary school, as well as forms of tests. ${ }^{17}$

The chronological (historical) principle was applied to the development of the secondary education standard in literature, emphasising literature as the artistic education of students while combining an introduction to the values of the world of art through mastery of knowledge and skills. ${ }^{18}$ Standards also indicated global historical eras and those of Latvian literature, indicating the most notable writers and poets of each era (mandatory minimum). As teachers created their curricula, they could choose to include personalities and literary works of other writers in addition to officially mandated authors.

Upon completion of secondary school, pupils had to pass a written exam that included an essay about a literary work, or the literary process of a writer or problematic or social processes featured in a work, as well as an oral exam in literature (according to Ministry of Education guidelines ${ }^{19}$ ). Pupils were required to know the content of main literary works and how to analyze the most important problems, and characters, including literary specifics. Analysis and assumptions had to be justified with facts and quotes from literature. The narrative had to be planned, logically coherent, expressed in smooth, correct language, and be desirably creative. ${ }^{20}$ Essays were corrected and oral exams evaluated during this period by each school's Methodological Committee of Latvian Language and Literature. ${ }^{21}$

During the early 1990s, learning specific subjects on an advanced level was introduced. ${ }^{22}$ Students could study advanced Latvian literature; the programme consisted of a basic course and an extended, in-depth version. It differed from

${ }^{17}$ Latvijas Republikas izglitíbas ministrija [Ministry of Education of the Republic of Latvia], Pamatizglìtības standarti latviešu valodā un literatūrā (projekts) [Primary education standards in the Latvian language and literature (draft)], Rìga, Latvijas Republikas izglitīibas ministrija, 1992, pp. 8-10.

${ }^{18}$ Latvijas Republikas izglitibas ministrija [Ministry of Education of the Republic of Latvia], Vidējās izglìtības standarti latviešu valodā un literatūrā [Secondary education standards in the Latvian language and literature], Rìga, Latvijas Republikas izglitïbas ministrija, 1993, p. 9.

${ }^{19}$ Latviešu literatūras eksāmena bil̨etes. Vidusskolas izlaiduma eksāmena bil̦etes 1994./95. mācību gadam [Latvian literature exam sheets. Secondary school graduation exam sheets for the 1994/95 study year], Rìga, Mācỉbu grāmata, 1995, pp. 26-29.

${ }^{20}$ Vidusskolas izlaiduma eksāmena biḷetes 1994./95. mācību gadam [Secondary school graduation exam sheets for the 1994/95 study year], Rìga, Mācību grāmata, 1995, p. 6.

${ }^{21}$ Groups of authorised methodology specialists that discussed and solved various methodology problems, developed subject learning methodology recommendations, and helped teachers in case of methodology issues. See A. Blinkena (ed.), Pedagogiijas terminu skaidrojošā vārdnīca [Interpretative dictionary of pedagogy terms], Riga, Zvaigzne ABC, 2000, p. 102.

${ }^{22}$ Subject in compliance with the main direction of the secondary education establishment offered in frame of in-depth learning of the educational programme. See A. Blinkena (ed.), Pedagoǵijas terminu skaidrojošā värdnīca [Interpretative dictionary of pedagogy terms], Rìga, Zvaigzne ABC, 2000, p. 139. 
the basic course in that six instead of four Latvian literature classes were planned per week. Thus, literature development processes were mastered in detail. There was one literature teacher for the class majoring in literature and another for the basic course. In the advanced oral exam, basic course tests were used by adding no more than one to two questions developed by the teacher based on the content of the advanced course or by replacing existing questions. Gradually, the guidelines of the advanced course were developed, defining the aims, content structure, examination forms, and methodology. ${ }^{23}$ Advanced course guidelines were introduced in the 1997/98 academic year, but the requirements only came into force in 1999/2000. Various advanced literature programmes for secondary schools were developed on the basis of these guidelines, such as curricula developed by Riga French Lyceum teachers Anita Vanaga and Gita Blaua ${ }^{24}$ they differed with the fact that curriculum content for the $10^{\text {th }}$ grade included Latvian literature development during the 1990s, with the justification that it provided insight into literary works that were closer to the thinking process of young people and reveal interests appropriate to their age, psychological perception, and experiences. They also indicate that "all works and authors included in the programme were selected by using knowledge and skills acquired during primary school so that one can create the necessity to understand literary works more deeply, bringing closer the life experience of the student with the writer's viewpoint about various phenomenon."25

Writers were initiators of this new literature standard project. Teachers, in cooperation with specialists from the Union of Writers, developed the basic education standard project. Also, renowned poets, literary researchers, critics, and translators took part in selection of educational content, highlighting the artistic qualities of literary works and their suitability to the age group of students. ${ }^{26}$ Before the basic education standard in literature was issued, Latvian language and literature specialists at the General Education Department at the Ministry of Education and Science (MoES) carefully assessed the latest projects, comparing them with existing documents and seriously considering the new content and actively discussing and negotiating: "Maybe it is still better to express one's attitude during the document development phase while it can be still corrected? Still, I am forced to remind you that people may have differing opinions; therefore, it is impossible to implement all the recommendations.... It seems we have to learn democracy together with our students - both expressing

${ }^{23}$ I. Spolīte (ed.), Literatūra. Profilkursa vadlinijas. Projekts [Literature. Advanced course guidelines. Draft], Rìga, Latvijas Republikas Izglìtības un zinātnes ministrijas Izglìtības satura eksaminācijas centrs, 1996, p. 16.

${ }^{24}$ G. Blaua, A. Vanaga, Literatūras programma vidusskolai. Profilkurss. Skolotāja grāmata [Literature programme for the secondary school. Advanced course. Teacher's book], Riga, Zvaigzne ABC, 1999, p. 24.

${ }^{25}$ Ibid., p. 2.

26 'Sākumizglìtỉbas vadlīnijas latviešu valodā' [Guidelines for primary education in Latvian], Izglìtība un Kultūra, pielikums 'Vispārējā izglìtîba' [Education and Culture, annex General education], 29 September 1994, p. 10. 
our opinion, learning to listen to others, and accepting their viewpoint, even if my opinion is not always the one that wins during this battle of opinions." ${ }^{27}$

In 2002, National Centre for Education (NCE) specialists issued the result of the work of MoES and NCE specialists, university teaching staff, and teachers: the material to be discussed was the basic education standard project in literature (approved by NCE on 15 November 2001), a document determining subject aims and tasks, contents of the mandatory subject, and requirements for the mastering of contents and evaluation forms and procedures. ${ }^{28}$ Contrary to the standards issued in 1992, literature was added to the field of arts. The standard project was based on humanitarian pedagogy ideas about individuality as a value, thus emphasising the guiding of individuals towards values during the study process and cooperation processes between teachers and students, as well as joint responsibility between students and teacher for results. It should be noted that for the first time, this aspect was mentioned in legislative documents for literature as a subject. It should be recognised that during literature lessons, not only the activity of the mind, understanding, and thinking processes were emphasised but also "visual perception, emotions, feelings, and self-expression in this versatile, artistic form, thus ensuring development of the harmonious individual within an ever-changing modern world, as well as mastering the specific knowledge and skills of the subject." ${ }^{29}$

The standards project determined a specific succession of knowledge, skills, and attitudes and a planned structure in the curriculum of local and foreign folklore, mythology, and literature. Literature learning included the following experiences: emotional, creative activity, evaluation, and cultural heritage mastery. The requirements regarding mandatory levels of knowledge upon completion of the $3^{\text {rd }}, 6^{\text {th }}$ and $9^{\text {th }}$ grades provided detailed outcomes in relation to each content component.

One of the innovations of the general education curriculum reform was development of a new evaluation system of the academic achievements of students. As mentioned before, changes in study content also changed the role of the teacher (how s/he teaches) and the student (how s/he learns). Therefore, the evaluation process of the student's academic achievements was transformed. Transition to a 10-point evaluation scale took place, as well as "pass" and "fail." Evaluation became more versatile, purposeful, and student-friendly. If previously the teacher was the main source of knowledge and pupil answers were evaluated according to "How many facts that I taught you have learned?", then now the task of teacher was to teach students to study and develop their skills according to the content of the subject. Students became co-responsible

\footnotetext{
27 'Sākumizglìīibas vadlīnijas latviešu valodā' [Guidelines for primary education in Latvian], Izglìtība un Kultūra, pielikums 'Vispārējā izglìtība' [Education and Culture, annex General education], 29 September 1994, p. 3.

${ }^{28}$ Literatūra. Pamatizglìtības standarta projekts. Materiāli apspriešanai [Literature. Project of primary education standard. Materials for discussion], Rỉga, Latvijas Republikas Izglitības un zinātnes ministrija, Izglìtỉbas satura un eksaminācijas centrs, 2002, pp. 5-12.

${ }^{29}$ Ibid., p. 6.
} 
and also partners of the teacher during the study process. ${ }^{30}$ This aspect was depicted in the draft of the elementary education standard in literature where, for the first time, explicit academic achievement evaluation forms and procedures were provided. Contrary to previous evaluation procedures in which the teacher was the main evaluator, this standard project emphasised mutual evaluation of students, self-evaluation, and various evaluation forms in literature, apart from evaluation by the teacher, as well as the state examination upon completion of $9^{\text {th }}$ grade.

The next step was development of the literature programme template, planned by NCE. It formulated the purposes and tasks of learning and the study content, as well as the logical succession of learning and planning, indications about the learning tools to be used, optimum methodological provisions, and evaluation forms, methods, criteria, and procedures to determine the students' academic achievements. Curricula templates were developed as a recommendation; they could vary, meaning that teaching could take place according to the didactic target, and specifics of the student age group and perception abilities could change the sequence of literary works by replacing the authors and works indicated in the programme with something else. NCE planned to develop this literature learning programme template but not attach it to a specific learning tool. The teacher could also develop the curriculum of her/ his subject in line with the standard planning structure regarding local and foreign folklore, mythology, and literature; determine the proportion of prose, poetry, and drama; choose literary works in line with the interests and needs of students; and develop versatile study methods and work organisation forms. ${ }^{31}$ It should be added that over time, there were various searches, experiments, and attempts to develop literature curricula. For example, the literature curricula for $5^{\text {th }}$ to $9^{\text {th }}$ grades, developed in 1993, were adopted by the Ministry of Education and were based on new knowledge about a specific type, genre, figurative approach, measure, etc. of the work of fiction or in-depth and expanded previously-acquired knowledge. ${ }^{32}$

On the background of other curricula, especially emphasising the interdependency of literature with other art forms involving artistic expression (periodicals, television, cinema, theatre), indication of mastery of literary works could take place not only in the classroom but also in the library, museum, writer's commemoration place, and during literary excursions. The fact that curricula took into consideration local regional literature, anniversaries of writers, and other literary festivals, thus expanding the perspective of students

${ }^{30}$ Vērtēšanas mērķi. Atbalsta materiāli skolotājiem [Evaluation targets. Support materials for teachers], Rīga, Latvijas Republikas Izglītības un zinātnes ministrija, Izglìtības satura un eksaminācijas centrs, 2004, p. 4.

${ }^{31}$ Literatūra. Pamatizglītības standarta projekts. Materiāli apspriešanai [Literature. Project of primary education standard. Materials for discussion], Rīga, Latvijas Republikas Izglìtības un zinātnes ministrija, Izglītības satura un eksaminācijas centrs, 2002, p. 12.

32 S. Urževica, Literatūras programma 5.-9. klasei [Literature programme for $5^{\text {th }}$ to $9^{\text {th }}$ grade], Rìga, 1993 , p. 47. 
and connection of the curricula acquired at school with the local community, is of great value.

\section{Conclusion}

Changes in literature learning from 1990 to 2004 indicate that after regaining independence, significant changes took place in the teaching/learning of literature: old curricula were revised, reviewed and altered for all age groups; literature learning standards, curricula templates, cooperation forms and methods for students and teachers, and academic achievement evaluation principles were developed. This period brought forward special meaning of literature as a subject of art for the development of harmonious individuals by accentuating aesthetic enjoyment and emotionally evaluating attitudes of literature, the meaning of co-creation and self-actualisation, and inclusion of the humanist, national, and local component into the content. 